\title{
Pengaruh Dosis Pupuk Kandang dan Jarak Tanam Terhadap Produksi Rumput Gajah Mini (Pennisetum purpureum cv. Mott)
}

\author{
Taufan P. Daru ${ }^{1}$, Odit F. Kurniadinata ${ }^{2}$, dan Yabel Noberto Patandean ${ }^{3}$ \\ 1,3 Jurusan Peternakan, Fakultas Pertanian Universitas Mulawarman, Samarinda \\ 2 Jurusan Agroteknologi, Fakultas Pertanian Universitas Mulawarman, Samarinda \\ 1 e-mail: taufan.pd@gmail.com
}

\begin{abstract}
This study was aimed to determine the effect of application of chicken manure and row spacing to the production components of dwarf elephant grass (Pennisetum purpureum cv. Mott). The experiment was carried out at Makroman village, Sambutan sub-district, in Samarinda city. Randomized block design (RBD) was used with a factorial pattern. Chicken manure dosage was the first factor consisted of 4 treatments, which were 0 ton $h^{-1}\left(p_{0}\right), 5$ ton ha-1 $\left(p_{1}\right), 10$ ton ha-1 $\left(p_{2}\right)$ and 15 ton ha- ${ }^{-1}$. The second treatment was row spacing that consists of 3 treatments, which were $50 \times 100 \mathrm{~cm}\left(k_{1}\right), 75 \times 100 \mathrm{~cm}(\mathrm{k} 2)$, and $100 \times 100 \mathrm{~cm}(\mathrm{k} 3)$. All treatments were replicated three times. Data were analyzed using analysis of variance method following by least significant difference post hoc at $5 \%$ significance. Variables observed included plant height, leaf length, leaves number, tillersn number, fresh weight, dry weight, and leaf/stem ratio. The results showed that the dosage of chicken manure gave significantly effect to plant height, leaf length, leaves number, tillers number, fresh weight and dry weight, while the row spacing treatment gave significantly affect to plant height, leaf length, dry weight, and leaf/stem ratio. There was no interaction effect between the two treatments to all measured production components of dwarf elephant grass.
\end{abstract}

Keywords: dwarf elephant grass, chicken manure, row spacing

\begin{abstract}
ABSTRAK
Tujuan penelitian adalah untuk mengetahui pengaruh pemberian pupuk kandang ayam dan jarak tanam yang berbeda terhadap komponen produksi rumput gajah mini (Pennisetum purpureum cv. Mott). Percobaan dilaksanakan di desa Makroman, kecamatan Sambutan, kota Samarinda. Rancangan yang digunakan adalah Rancangan Acak Kelompok (RAK) dengan pola faktorial, dimana perlakuan dosis pupuk kandang ayam terdiri atas 4 perlakuan, yaitu 0 ton ha-1 $\left(p_{0}\right), 5$ ton ha- ${ }^{-1}\left(p_{1}\right), 10$ ton ha-1 $\left(p_{2}\right)$ dan 15 ton ha ${ }^{-1}\left(p_{3}\right)$, sedangkan perlakuan jarak tanam terdiri atas 3 perlakuan, yaitu $50 \times 100 \mathrm{~cm}\left(\mathrm{k}_{1}\right), 75 \times 100 \mathrm{~cm}(\mathrm{k} 2)$, dan $100 \times 100 \mathrm{~cm}(\mathrm{k} 3)$. Seluruh perlakuan diulang sebanyak 3 kali. Data dianalisis dengan analisis sidik ragam yang dilanjutkan dengan uji beda nyata terkecil pada taraf $5 \%$. Variabel yang diamati meliputi tinggi tanaman, panjang daun, jumlah daun, jumlah anakan, berat segar, berat kering, dan imbangan daun/batang. Hasil penelitian menunjukkan bahwa dosis pupuk kandang ayam memberikan pengaruh yang nyata terhadap tinggi tanaman, panjang daun, jumlah daun, jumlah anakan, berat segar dan berat kering, sedangkan perlakuan jarak tanam berpengaruh nyata pada tinggi tanaman, panjang daun, berat kering, dan imbangan daun/batang. Tidak terjadi interaksi antara perlakuan dosis pupuk kandang dan jarak tanam terhadap seluruh komponen produksi rumput gajah mini yang diukur.

Kata kunci: rumput gajah mini, pupuk kandang ayam, jarak tanam
\end{abstract}

\section{Pendahuluan}

Pakan ternak merupakan aspek penting yang menentukan keberhasilan suatu peternakan. Khusus bagi ternak ruminansia ketersediaan hijauan pakan, baik secara kualitas maupun kuantitas akan mempengaruhi pengembangan suatu usaha peternakan. Oleh karena itu, ketersediaan hijauan pakan harus tersedia secara kontinu baik kualitas maupun kuantitas. Upaya yang dapat dilakukan adalah meningkatkan produksi, serta 
ISSN 2354-7251 (print)

pertumbuhan dan perkembangan hijauan pakan (Lasamadi et al., 2013). Pemupukan merupakan salah satu cara meningkatkan produksi suatu tanaman. Hal ini tak lepas dari peran pupuk dalam memenuhi ketersediaan hara yang cukup bagi pertumbuhan tanaman secara kontinyu bagi tanaman. Berdasarkan sumbernya, pupuk dibedakan menjadi dua kelompok, yaitu pupuk anorganik dan pupuk organik. Pupuk organik, seperti pupuk kandang dari kotoran ayam, memiliki keunggulan dalam hal memperbaiki sifat - sifat fisik tanah seperti permeabilitas tanah, porositas tanah, struktur tanah, daya menahan air, dan kation-kation tanah (Roidah, 2013). Pupuk organik juga dapat menyediakan unsur hara yang lengkap dan berimbang yang dapat diserap oleh tanaman, sehingga merupakan faktor yang penting dalam menentukan pertumbuhan dan produksi tanaman (Dewanto et al., 2013). Penggunaan pupuk kandang pada umumnya lebih banyak dibandingkan pupuk anorganik, namun dalam jangka waktu yang panjang akan lebih aman dibandingkan dengan pupuk anorganik, sehingga dapat mempertahankan produksi tanaman.

Rumput gajah mini merupakan jenis rumput hijauan pakan yang potensial untuk dikembangkan di Indonesia. Menurut Lasamadi et al. (2013) rumput gajah mini merupakan tanaman yang produktif dan dapat menghasilkan anakan yang cukup banyak, mempunyai akar kuat, batang yang tidak keras dan mempunyai ruas daun yang banyak serta struktur daun yang muda sehingga sangat disukai oleh ternak. Jarak tanam merupakan suatu bentuk perlakuan pada tanaman dengan mengatur jarak antar tanaman satu dengan tanaman yang lain pada suatu lahan/areal pembudidayaan. Jarak tanam sangat berkaitan dengan kerapatan tanaman, dimana kerapatan tanaman perlu diperhatikan dalam pembudidayaan untuk menentukan sasaran agronomi, yaitu produksi maksimum (Jumin, 1991). Pengaturan jarak tanam pada suatu areal tanah pertanian merupakan salah satu cara yang berpengaruh terhadap hasil yang akan dicapai (Azis dan Arman, 2013). Hal ini berkaitan dengan adanya persaingan dalam penggunaan hara, air, cahaya, dan ruang tumbuh yang dapat menjadi penghambat antar tanaman untuk tumbuh. Pernyataan ini didukung Azis dan Arman (2013) yang mengatakan bahwa jarak tanam juga mempengaruhi persaingan antar tanaman dalam mendapatkan air dan unsur hara, sehingga akan mempengaruhi hasil. Penelitian yang dilakukan oleh Kusdiana et al. (2017) menjelaskan bahwa produksi rumput gajah mini pada perlakuan jarak tanam $80 \times 80 \mathrm{~cm}$ memberikan produksi rumput gajah mini yang lebih baik, yaitu pada rata-rata tinggi tanaman menunjukkan $84,05 \mathrm{~cm}$, dengan rata-rata berat segar 471,25 g. Penelitian ini bertujuan untuk mengetahui pengaruh pemberian dosis pupuk kandang dari kotoran ayam dan pengaturan jarak tanam yang berbeda terhadap produksi rumput gajah mini. 


\section{Metodologi Penelitian}

Penelitian dilakukan selama 5 bulan terhitung sejak pengolahan lahan pada bulan Februari sampai dengan Juni 2018 di Kelurahan Makroman, Kecamatan Sambutan, Samarinda. Bahan yang digunakan dalam penelitian ini adalah stek rumput gajah mini dan pupuk kotoran ayam. Media tanah dalam penelitian ini merupakan tanah ultisol yang memiliki kandungan $\mathrm{pH} 3,8, \mathrm{C}$-organik $0,36 \%, \mathrm{~N}$ total $0,11 \%, \mathrm{C} / \mathrm{N}$ ratio $3, \mathrm{P}$ tersedia 4,47 ppm, K tersedia 27,50 ppm, $\mathrm{Ca}^{++} 0,80 \mathrm{meq} / 100 \mathrm{~g}, \mathrm{Mg}^{++} 0,34 \mathrm{meq} / 100 \mathrm{~g}, \mathrm{~K}^{+}$0,08 meq/100 g, Na+ 0,07 meq/100 g, KTK 4,35, dan Kejenuhan Basa 29,77\%.

Percobaan disusun dalam rancangan acak kelompok (RAK)dengan pola faktorial. Rancangan dipilih untuk mengantisipasi perbedaan variasi lingkungan tempat stek ditanam. Faktor pertama adalah dosis pupuk kandang kotoran ayam (p) yang terdiri atas 4 taraf, yaitu : $p_{0}=$ dosis pupuk $0 \mathrm{~kg} \mathrm{ha}^{-1}$ (kontrol); $\mathrm{p}_{1}=$ dosis pupuk 5 ton ha-1 setara dengan 12,5 $\mathrm{kg}_{\text {petak }}{ }^{-1} ; \mathrm{p}_{2}=$ dosis pupuk 10 ton ha ${ }^{-1}$ setara dengan $25 \mathrm{~kg}_{\text {petak }}{ }^{-1} ; \mathrm{p}_{3}=$ dosis pupuk 15 ton ha ${ }^{-1}$ setara dengan $37,5 \mathrm{~kg}$ petak $^{-1}$. Ukuran petak menyesuaikan dengan jarak tanam. Faktor kedua adalah jarak tanam ( $k$ ) yang terdiri dari 3 taraf, yaitu : $\mathrm{k}_{1}=$ jarak tanam $50 \mathrm{~cm}$ x $100 \mathrm{~cm} ; \mathrm{k}_{2}=$ jarak tanam $75 \mathrm{~cm} \times 100 \mathrm{~cm}$; dan $\mathrm{k}_{3}=$ jarak tanam $100 \mathrm{~cm} \times 100 \mathrm{~cm}$. Seluruh perlakuan diulang sebanyak 3 kali. Variabel yang diamati adalah tinggi tanaman, panjang daun, jumlah daun, jumlah anakan, berat segar, berat kering, dan imbangan daun/batang. Pengambilan data dilakukan pada umur tanaman 40 hari setelah trimming. Data yang diperoleh dianalisis dengan sidik ragam, apabila terdapat perbedaan yang nyata dilanjutkan dengan uji beda nyata terkecil (BNT) pada taraf $5 \%$.

\section{Hasil dan Pembahasan}

\section{Karakteristik Morfologi}

Hasil sidik ragam perlakuan dosis pupuk kandang dari kotoran ayam dan jarak tanam terhadap tinggi tanaman dan panjang daun rumput gajah mini menunjukkan perbedaan yang nyata $(P<0,05)$. Namun, tidak menunjukkan adanya interaksi antara dosis pupuk kandang ayam dengan perlakuan jarak tanam terhadap tinggi tanaman dan panjang daun. Rata-rata tinggi tanaman disajikan pada Tabel 1 sedangkan rata-rata panjang daun rumput gajah mini disajikan pada Tabel 2.

Hasil sidik ragam perlakuan dosis pupuk kandang ayam terhadap jumlah daun dan jumlah anakan rumput gajah mini menunjukkan perbedaan yang nyata $(P<0,05)$, namun pada perlakuan jarak tanam menunjukkan perbedaan yang tidak nyata $(P>0,05)$. Begitupula dalam hal perlakuan dosis pupuk kandang ayam dan perlakuan jarak tanam juga tidak menunjukkan adanya interaksi terhadap jumlah daun dan jumlah anakan rumput gajah mini. Rata-rata jumlah daun rumput gajah mini disajikan pada Tabel 3 sedangkan rata-rata jumlah anakan rumput gajah mini disajikan pada Tabel 4 . 
ISSN 2354-7251 (print)

Tabel 1. Rata-rata tinggi rumput gajah mini pada perlakuan pupuk kandang ayam dan jarak tanam yang berbeda

\begin{tabular}{|c|c|c|c|c|c|}
\hline \multirow{2}{*}{$\begin{array}{c}\text { Jarak } \\
\text { tanam }\end{array}$} & \multicolumn{4}{|c|}{ Dosis pupuk kandang ayam } & \multirow[t]{2}{*}{ Rata-rata* } \\
\hline & $p_{0}$ & $\mathbf{p}_{1}$ & $\mathbf{p}_{2}$ & $\mathbf{p}_{3}$ & \\
\hline & & .. $\mathrm{cm}$ & $\ldots$ & $\ldots \ldots$ & \\
\hline $\mathrm{k}_{1}$ & 135,67 & 157,86 & 160,74 & 164,59 & $154,71 \pm 12,99^{a}$ \\
\hline $\mathrm{k}_{2}$ & 82,01 & 99,50 & 96,77 & 104,30 & $95,64 \pm 9,61^{b}$ \\
\hline $\mathrm{k}_{3}$ & 73,58 & 86,80 & 86,08 & 84,39 & $82,71 \pm 6,17^{c}$ \\
\hline Rata-rata* & $97,09 \pm 33,68^{c}$ & $114,72 \pm 37,90^{b}$ & $\begin{array}{l}114,53 \pm \\
4037 \mathrm{abc}\end{array}$ & $117,76 \pm 41$ & \\
\hline
\end{tabular}

Keterangan: $\mathrm{p}_{0}=$ dosis pupuk 0 ton ha-1 (kontrol); $\mathrm{p}_{1}=$ dosis pupuk 5 ton ha-1; $\mathrm{p}_{2}=$ dosis pupuk 10 ton ha-1; $\mathrm{p}_{3}$ $=$ dosis pupuk 15 ton ha-1; $\mathrm{k}_{1}=$ jarak tanam $50 \times 100 \mathrm{~cm} ; \mathrm{k}_{2}=$ jarak tanam $75 \times 100 \mathrm{~cm} ; \mathrm{k}_{3}=$ jarak tanam $100 \times 100 \mathrm{~cm}$. *Angka rata-rata yang didampingi superskrip yang sama pada kolom yang sama atau pada baris yang sama menunjukkan perbedaan yang tidak nyata pada uji BNT 5\% ( $p=$ $8,90)$; uji BNT 5\% $(\mathrm{k}=7,71)$.

Tabel 2. Rata-rata panjang daun rumput gajah mini pada perlakuan pupuk kandang ayam dan jarak tanam yang berbeda

\begin{tabular}{|c|c|c|c|c|c|}
\hline \multirow{2}{*}{$\begin{array}{c}\text { Jarak } \\
\text { tanam }\end{array}$} & \multicolumn{4}{|c|}{ Dosis pupuk kandang ayam } & \multirow[t]{2}{*}{ Rata-rata* } \\
\hline & $p_{0}$ & $\mathbf{p}_{1}$ & $\mathbf{p}_{2}$ & $p_{3}$ & \\
\hline & & . & & & \\
\hline $\mathrm{k}_{1}$ & 93,86 & 109,51 & 116,34 & 119,15 & $109,71 \pm 11,32^{a}$ \\
\hline $\mathrm{k}_{2}$ & 59,83 & 68,70 & 67,84 & 71,53 & $66,98 \pm 5,02^{b}$ \\
\hline $\mathrm{k}_{3}$ & 53,07 & 58,96 & 58,24 & 60,91 & $57,79 \pm 3,35^{c}$ \\
\hline
\end{tabular}

$\begin{array}{lllll}\text { Rata-rata* }^{*} 68,92 \pm 21,86^{\mathrm{c}} & 79,06 \pm 26,82^{\mathrm{b}} & 80,81 \pm 31,14^{\mathrm{abc}} & 83,86 \pm 31,02^{\mathrm{a}}\end{array}$

Keterangan: $\mathrm{p}_{0}=$ dosis pupuk 0 ton ha ${ }^{-1}$ (kontrol); $\mathrm{p}_{1}=$ dosis pupuk 5 ton ha-1; $\mathrm{p}_{2}=$ dosis pupuk 10 ton $\mathrm{ha}^{-1}$; $\mathrm{p}_{3}=$ dosis pupuk 15 ton $\mathrm{ha}^{-1} ; \mathrm{k}_{1}=$ jarak tanam $50 \times 100 \mathrm{~cm} ; \mathrm{k}_{2}=$ jarak tanam $75 \times 100 \mathrm{~cm} ; \mathrm{k}_{3}$ $=$ jarak tanam $100 \times 100 \mathrm{~cm}$. *Angka rata-rata yang didampingi superskrip yang sama pada kolom yang sama atau pada baris yang sama menunjukkan perbedaan yang tidak nyata pada uji BNT 5\% $(p=5,59)$; uji BNT 5\% $(k=4,84)$.

Tabel 3. Rata-rata jumlah daun rumput gajah mini pada perlakuan pupuk kandang ayam dan jarak tanam yang berbeda

\begin{tabular}{|c|c|c|c|c|c|}
\hline \multirow{2}{*}{ Jarak tanam } & \multicolumn{4}{|c|}{ Dosis pupuk kandang ayam } & \multirow{2}{*}{ Rata-rata } \\
\hline & $\mathbf{p}_{0}$ & $p_{1}$ & $\mathbf{p}_{2}$ & $\mathbf{p}_{3}$ & \\
\hline & & $\ldots .1$ & & . & \\
\hline $\mathrm{k}_{1}$ & 138,11 & 201,44 & 267,94 & 242,19 & $212,42 \pm 56,60$ \\
\hline $\mathrm{k}_{2}$ & 95,27 & 191,03 & 202,77 & 278,77 & $191,96 \pm 75,28$ \\
\hline $\mathrm{k}_{3}$ & 110,89 & 211,22 & 215,56 & 225,56 & $190,81 \pm 53,61$ \\
\hline
\end{tabular}

$\begin{array}{lllll}\text { Rata-rata* }^{*} & 114,76 \pm 21,68^{\mathrm{c}} & 201,23 \pm 10,10^{\mathrm{b}} & 228,76 \pm 34,54^{\text {ab }} & 248,84 \pm 27,22^{\mathrm{a}}\end{array}$

Keterangan: $\mathrm{p}_{0}=$ dosis pupuk 0 ton ha- ${ }^{-1}\left(\right.$ kontrol); $\mathrm{p}_{1}=\operatorname{dosis}$ pupuk 5 ton $\mathrm{ha}^{-1} ; \mathrm{p}_{2}=\operatorname{dosis}$ pupuk 10 ton ha-1; $\mathrm{p}_{3}=$ dosis pupuk 15 ton ha ${ }^{-1} ; \mathrm{k}_{1}=$ jarak tanam $50 \times 100 \mathrm{~cm} ; \mathrm{k}_{2}=$ jarak tanam $75 \times 100 \mathrm{~cm} ; \mathrm{k}_{3}=$ jarak tanam $100 \times 100 \mathrm{~cm}$. *Angka rata-rata yang didampingi superskrip yang sama pada pada baris yang sama menunjukkan perbedaan yang tidak nyata pada uji BNT 5\% $(p=70,89)$

Penambahan pupuk kandang ayam ke dalam tanah dapat menambah unsur hara yang bermanfaat bagi proses pertumbuhan tinggi tanaman, khususnya pada bagian batang dan daun dalam penelitian ini. Pupuk kandang dari kotoran ayam memiliki kandunganunsur hara makro, seperti nitrogen $(N)$, fosfor $(P)$, dan kalium $(K)$ yang lebih tinggi dibandingkan dengan pupuk kandang sapi dan kambing (Arifah, 2013), sehingga mampu meningkatkan tinggi tanaman, pemanjangan daun, hingga perbanyakan anakan pada kondisi lahan yang miskin hara. Hal ini disebabkan unsur nitrogen berperan dalam proses pembelahan sel sehingga dapat merangsang pertumbuhan secara keseluruhan, 
khususnya pertumbuhan batang sehingga yang dapat memicu pertumbuhan tinggi tanaman (Saputri et al., 2018).

Tabel 4. Rata-rata jumlah anakan rumput gajah mini pada perlakuan pupuk kandang ayam dan jarak tanam yang berbeda

\begin{tabular}{|c|c|c|c|c|c|}
\hline \multirow{2}{*}{$\begin{array}{c}\text { Jarak } \\
\text { tanam }\end{array}$} & \multicolumn{4}{|c|}{ Dosis pupuk kandang ayam } & \multirow[t]{2}{*}{ Rata-rata } \\
\hline & $p_{0}$ & $p_{1}$ & $\mathbf{p}_{2}$ & $p_{3}$ & \\
\hline \multicolumn{6}{|c|}{ pols } \\
\hline $\mathrm{k}_{1}$ & 14,97 & 21,06 & 28,86 & 29,44 & $23,58 \pm 6,90$ \\
\hline $\mathrm{k}_{2}$ & 10,70 & 18,40 & 22,10 & 28,13 & $19,83 \pm 7,29$ \\
\hline $\mathrm{k}_{3}$ & 11,15 & 21,33 & 21,78 & 24,00 & $19,56 \pm 5,73$ \\
\hline Rata-rata* & $12,27 \pm 2,35^{c}$ & $20,26 \pm 1,62^{b}$ & $24,25 \pm 4,00^{\mathrm{ab}}$ & \multicolumn{2}{|l|}{$27,19 \pm 2,84^{\mathrm{a}}$} \\
\hline \multicolumn{6}{|c|}{$\begin{array}{l}\text { Keterangan: } p_{0}=\text { dosis pupuk } 0 \text { ton ha }{ }^{-1}(\text { kontrol }) ; p_{1}=\text { dosis pupuk } 5 \text { ton ha } \mathrm{ha}^{-1} ; \mathrm{p}_{2}=\text { dosis pupuk } 10 \\
\text { ton ha } \mathrm{h}^{-1} ; \mathrm{p}_{3}=\text { dosis pupuk } 15 \text { ton ha }{ }^{-1} ; \mathrm{k}_{1}=\text { jarak tanam } 50 \times 100 \mathrm{~cm} ; \mathrm{k}_{2}=\text { jarak tanam } \\
75 \times 100 \mathrm{~cm} ; \mathrm{k}_{3}=\text { jarak tanam } 100 \times 100 \mathrm{~cm} \text {. }{ }^{\star} \text { Angka rata-rata yang didampingi } \\
\text { superskrip yang sama pada pada baris yang sama menunjukkan perbedaan yang tidak } \\
\text { nyata pada uji BNT } 5 \%(\mathrm{p}=4,97) .\end{array}$} \\
\hline
\end{tabular}

Selain nitrogen, kandungan fosfor juga mempengaruhi pertumbuhan rumput gajah mini, dimana peran fosfor penting untuk perkembangan akar, pertumbuhan awal akar tanaman, luas daun, dan mempercepat panen (Adam et al., 2013; Kurniadinata et al., 2018). Unsur ini sangat diperlukan oleh tanaman pada awal penanaman, dimana dengan berkembangnya akar akan membantu tanaman dalam penyerapan air dan unsur-unsur hara lainnya dari dalam tanah yang selanjutnya digunakan dalam fotosintesis pada kondisi lahan yang kering.

Kalium berperan dalam proses respirasi dan meningkatkan ketahanan tanaman terhadap serangan hama dan penyakit (Firmansyah et al., 2017). Oleh karena itu, dengan tersedianya unsur $\mathrm{K}$ yang cukup dapat membantu tanaman untuk memperoleh energi melalui proses respirasi sehingga dapat menunjang pembelahan sel dan berpengaruh terhadap tinggi tanaman, pemanjangan daun, penambahan jumlah daun, hingga munculnya anakan baru.

Jenis tanah yang digunakan dalam penelitian ini adalah tanah ultisol yang memiliki kandungan bahan organik sangat rendah $(0,36 \%)$ kapasitas tukar kation (KTK) yang juga sangat rendah $(4,35 \mathrm{meq} / 100 \mathrm{~g})$ serta kurang kuat dalam memegang hara, akibatnya hara mudah tercuci (Agusni et al., 2014). Pemberian pupuk kandang ayam, selain memperbaiki sifat kimiawi tanah, juga memperbaiki sifat fisik dan biologis tanah. Pupuk kandang ayam selain menambah unsur hara dalam tanah, juga menurut Ramli et al., (2016) mampu memperbaiki struktur tanah, menambah bahan organik tanah, meningkatkan kapasitas menahan air sehingga pertumbuhan akar semakin baik. Oleh karena itu, pemberian pupuk kandang ayam pada jenis tanah ultisol sangat membantu sistem perakaran tanaman dalam menyerap secara maksimal air yang ada di dalam tanah dan menjadi sumber hara utama bagi tanaman, terlebih pada awal penanaman yang cenderung membutuhkan air dan unsur hara dalam jumlah yang banyak. 
Pengaturan jarak tanam sangat erat kaitannya dengan persaingan hara antar tanaman yang berdampak pada pertumbuhan tanaman. Pengaturan jarak tanam mempengaruhi populasi tanaman, persaingan tanaman akan hara, penggunaan energi berupa cahaya matahari, hingga ruang tumbuh tanaman. Menurut Erawati dan Hipi (2016), jarak tanam yang populasinya rapat cenderung menyebabkan tanaman akan bertambah tinggi, karena ruang gerak tanaman terbatas, sehingga tanaman akan berusaha mencari sinar matahari dengan memperpanjang organ tanaman. Pernyataan ini diperkuat oleh Silaban et al., (2013) bahwa peningkatan kerapatan berakibat tanaman lebih tinggi.

Pertumbuhan tinggi tanaman yang tinggi disebabkan oleh ruang tumbuh tanaman yang semakin sempit sehingga kompetisi cahaya antar individu semakin besar. Kondisi demikian membuat tanaman akan memanjangkan daun agar dapat menyerap lebih banyak sinar matahari yang digunakan sebagai sumber energi pada proses fotosintesis. Wahyudin et al., (2017) menyatakan bahwa ruang tumbuh yang rapat akan membuat tajuk tanaman saling menaungi satu sama lain sehingga akan menutupi area luasan tanah, akibatnya cahaya matahari dapat diserap lebih banyak oleh tanaman. Hal ini sebagai bagian dari respon tanaman agar dapat bersaing, terlebih pada lahan yang minim hara dengan persaingan yang tinggi.

\section{Karakteristik Produksi}

Hasil sidik ragam perlakuan dosis pupuk kandang ayam terhadap berat segar dan berat kering rumput gajah mini menunjukkan perbedaan yang nyata $(P<0,05)$, sedangkan pada perlakuan jarak tanam maupun interaksinya dengan dosis pupuk kandang ayam menunjukkan perbedaan yang tidak nyata. Rata-rata berat segar disajikan pada Tabel 5 dan rata-rata berat kering rumput gajah mini disajikan pada Tabel 6.

Berbeda dengan berat segar dan berat kering, dalam hal imbangan daun/batang perlakuan jarak tanam menunjukkan perbedaan yang nyata $(P<0,05)$, sedangkan pada perlakuan dosis pupuk kandang ayam maupun interaksinya dengan jarak tanam menunjukkan perbedaan yang tidak nyata $(P<0,05)$. Rata-rata imbangan daun/batang rumput gajah mini disajikan pada Tabel 7 .

Tabel 5. Rata-rata berat segar rumput gajah mini pada perlakuan pupuk kandang ayam dan jarak tanam yang berbeda

\begin{tabular}{|c|c|c|c|c|c|}
\hline \multirow{2}{*}{$\begin{array}{c}\text { Jarak } \\
\text { Tanam }\end{array}$} & \multicolumn{4}{|c|}{ Dosis pupuk kandang ayam } & \multirow[t]{2}{*}{ Rata-rata } \\
\hline & po & $\mathbf{p}_{1}$ & $\mathbf{p}_{2}$ & $\mathbf{p}_{3}$ & \\
\hline & \multicolumn{5}{|c|}{ 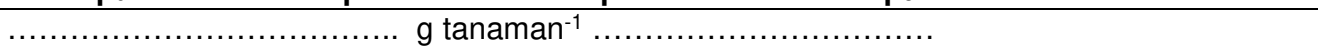 } \\
\hline $\mathrm{k}_{1}$ & 580,56 & $1.002,78$ & $1.741,67$ & $1.786,11$ & $1.277,78 \pm 587,46$ \\
\hline $\mathrm{k}_{2}$ & 356,67 & 860,00 & $1.513,33$ & $1.820,00$ & $1.137,50 \pm 656,70$ \\
\hline $\mathrm{k}_{3}$ & 596,30 & $1.135,19$ & $1.203,70$ & $1.470,40$ & $1.101,40 \pm 366,47$ \\
\hline Rata-rata* & $511,1 \pm 134,04^{c}$ & $999,32 \pm 137,63^{b}$ & $1.486,23 \pm 270,00^{\mathrm{a}}$ & $1.692,17 \pm 192,81^{\mathrm{a}}$ & \\
\hline
\end{tabular}


Tabel 6. Rata-rata berat kering rumput gajah mini pada perlakuan pupuk kandang ayam dan jarak tanam yang berbeda

\begin{tabular}{|c|c|c|c|c|c|}
\hline \multirow{2}{*}{ Jarak tanam } & \multicolumn{4}{|c|}{ Dosis pupuk kandang ayam } & \multirow{2}{*}{ Rata-rata } \\
\hline & $p_{0}$ & $\mathbf{p}_{1}$ & $\mathbf{p}_{2}$ & $p_{3}$ & \\
\hline \multicolumn{6}{|c|}{$\mathrm{g}$ tanaman $^{-1} \ldots \ldots$} \\
\hline $\mathrm{k}_{1}$ & 49,14 & 94,17 & 101,69 & 128,78 & $93,44 \pm 33,07$ \\
\hline $\mathrm{k}_{2}$ & 46,47 & 89,00 & 99,17 & 118,10 & $88,18 \pm 30,31$ \\
\hline $\mathrm{k}_{3}$ & 42,30 & 81,04 & 92,48 & 113,89 & $82,43 \pm 30,02$ \\
\hline Rata-rata* & $45,97 \pm 3,45^{d}$ & $88,07 \pm 6,61^{c}$ & $97,78 \pm 4,76^{\mathrm{bc}}$ & $120,26 \pm 7,67^{a}$ & \\
\hline
\end{tabular}

Keterangan: $\mathrm{p}_{0}=$ dosis pupuk 0 ton ha- ${ }^{-1}\left(\right.$ kontrol); $\mathrm{p}_{1}=$ dosis pupuk 5 ton ha ${ }^{-1} ; \mathrm{p}_{2}=$ dosis pupuk 10 ton ha $\mathrm{ha}^{-1} ; \mathrm{p}_{3}$ $=$ dosis pupuk 15 ton ha ${ }^{-1} ; \mathrm{k}_{1}=$ jarak tanam $50 \times 100 \mathrm{~cm} ; \mathrm{k}_{2}=$ jarak tanam $75 \times 100 \mathrm{~cm} ; \mathrm{k}_{3}=$ jarak tanam $100 \times 100 \mathrm{~cm}$. *Angka rata-rata yang didampingi superskrip yang sama pada pada baris yang sama menunjukkan perbedaan yang tidak nyata pada uji BNT $5 \%(p=19,01)$.

Tabel 7. Rata-rata imbangan daun/batang rumput gajah mini pada perlakuan pupuk kandang ayam dan jarak tanam yang berbeda

\begin{tabular}{|c|c|c|c|c|c|}
\hline \multirow{2}{*}{ Jarak tanam } & \multicolumn{4}{|c|}{ Dosis pupuk kandang ayam } & \multirow{2}{*}{ Rata-rata* } \\
\hline & po & $p_{1}$ & $p_{2}$ & $p_{3}$ & \\
\hline $\mathrm{k}_{1}$ & 2,65 & 2,80 & 2,96 & 2,70 & $2,78 \pm 0,13^{a}$ \\
\hline $\mathrm{k}_{2}$ & 2,11 & 2,09 & 2,10 & 2,22 & $2,13 \pm 0,06^{b}$ \\
\hline $\mathrm{k}_{3}$ & 2,09 & 2,13 & 2,03 & 2,19 & $2,11 \pm 0,07^{b c}$ \\
\hline Rata-rata & $2,28 \pm 0,32$ & $2,34 \pm 0,40$ & $2,36 \pm 0,52$ & $2,37 \pm 0,28$ & \\
\hline \multicolumn{6}{|c|}{$\begin{array}{r}\text { Keterangan: } p_{0}=\text { dosis pupuk } 0 \text { ton ha } \text { h }^{-1}(\text { kontrol }) ; p_{1}=\text { dosis pupuk } 5 \text { ton ha }{ }^{-1} ; p_{2}=\text { dosis pupuk } \\
10 \text { ton ha-1 } ; p_{3}=\text { dosis pupuk } 15 \text { ton ha }{ }^{-1} ; k_{1}=\text { jarak tanam } 50 \times 100 \mathrm{~cm} ; \mathrm{k}_{2}= \\
\text { jarak tanam } 75 \times 100 \mathrm{~cm} ; \mathrm{k}_{3}=\text { jarak tanam } 100 \times 100 \mathrm{~cm} .{ }^{*} \text { Angka rata-rata yang } \\
\text { didampingi superskrip yang sama pada pada kolom yang sama menunjukkan } \\
\text { perbedaan yang tidak nyata pada uji BNT } 5 \%(\mathrm{k}=0,21) .\end{array}$} \\
\hline
\end{tabular}

Produksi sangat erat hubungannya dengan pertumbuhan. Peranan nitrogen yang terkandung dalam pupuk kandang ayam membuat daun banyak mengandung klorofil yang berperan penting dalam proses fotosintesis (Istikomah dan Kunharjanti, 2017). Semakin banyaknya klorofil pada daun yang merupakan organ penting fotosintesis, membuat daun semakin banyak menyerap sinar matahari sehingga dapat meningkatkan hasil fotosintesis, terutama glukosa yang digunakan oleh tanaman untuk bertumbuh dan berkembang. Hal ini terlihat pada bertambahnya jumlah daun, dan jumlah anakan baru, sekalipun pada kondisi lahan yang minim unsur hara. Sari et al., (2016) menyatakan bahwa dengan meningkatnya jumlah daun tanaman, maka akan meningkatkan berat segar tanaman. Oleh karena itu, peningkatan dosis pupuk kandang ayam juga meningkatkan produksi berat segar rumput gajah mini yang dicerminkan juga oleh meningkatnya produksi berat kering.

Perlakuan jarak tanam tidak berpengaruh pada berat segar dan berat kering rumput gajah mini, tetapi berpengaruh nyata pada imbangan daun/batang rumput gajah mini. Pada jarak tanam $50 \mathrm{~cm} \times 100 \mathrm{~cm}$ menunjukkan rata-rata imbangan daun/batang tertinggi yaitu 2,78, dan pada jarak tanam $100 \mathrm{~cm} \times 100 \mathrm{~cm}$ menunjukkan rataan imbangan daun/batang terendah, yaitu 2,11. Kondisi demikian masih berkaitan dengan hasil yang ditunjukkan dari pertumbuhan rumput gajah mini berupa tinggi tanaman dan panjang daun, di mana pada jarak tanam yang rapat menunjukkan rasio daun lebih tinggi bila dibandingkan dengan rasio batang sehingga pada kondisi kering sekalipun juga tetap akan terlihat imbangan daun/batang rumput gajah mini yang tinggi pada jarak tanam yang rapat yaitu $50 \mathrm{~cm} \times 100$ 
ISSN 2354-7251 (print)

cm. Menurut Kusdiana et al. (2017) karakteristik perbandingan rasio daun rumput gajah mini lebih tinggi dibandingkan dengan batang. Selain itu, jarak tanam $50 \mathrm{~cm} \times 100 \mathrm{~cm}$ dianggap sebagai jarak tanam yang ideal bagi pertumbuhan dan perkembangan rumput gajah mini bila dibandingkan dengan jarak tanam yang lainnya (Sirait, 2013).

\section{Kesimpulan}

Berdasarkan hasil penelitian ini disimpulkan bahwa produksi rumput gajah mini dipengaruhi oleh dosis pupuk kandang ayam, dimana dengan meningkatnya dosis pupuk

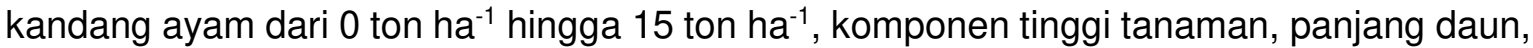
jumlah daun, jumlah anakan, berat segar, dan berat kering semakin meningkat. Sedangkan jarak tanam hanya berpengaruh terhadap tinggi tanaman, panjang daun, dan imbangan daun/batang. Dalam penelitian ini juga menunjukkan tidak adanya interaksi antara dosis pupuk kandanga ayam dan jarak tanam terhadap semua komponen produksi rumput gajah mini.

\section{Daftar Pustaka}

Adam, S.Y., M. I. Bahua, \& F. S. Jamin. (2013). Pengaruh Pupuk Fosfor pada Pertumbuhan dan Produksi Tanaman Mentimun (Cucumis sativus L.). KIM Fakultas IImu-IImu Pertanian. Vol 1(1): 1-24.

Agusni, Marlina, \& H. Satriawan. (2014). Pengaruh Olah Tanah dan Pemberian Pupuk Kandang Terhadap Sifat Fisik Tanah dan Produksi Tanaman Jagung. Lentera. Vol 14 (11): 1-6.

Arifah, S.M. (2013). Aplikasi Macam dan Dosis Pupuk Kandang pada Tanaman Kentang. Jurnal Gamma. Vol 8 (2): 80-85.

Azis, A.H., \& Arman. (2013). Respons Jarak Tanam dan Dosis Pupuk Organik Granul yang Berbeda Terhadap Pertumbuhan dan Produksi Tanaman Jagung Manis. Jurnal Agrisistem. Vol 9 (1): 16-23.

Dewanto, F.G., J.J.M.R. Londok, R.A.V. Tuturoong, \& W. B. Kaunang. (2013). Pengaruh Pemupukan Anorganik Dan Organik Terhadap Produksi Tanaman Jagung Sebagai Sumber Pakan. Jurnal Zootek. Vol 32 (5): 1-8.

Erawati, B.T.R., \& A. Hipi. (2016). Pengaruh Jarak Tanam Terhadap Pertumbuhan Dan Hasil Beberapa Varietas Jagung Hibrida di Kawasan Pengembangan Jagung Kabupaten Sumbawa. Prosiding Seminar Nasional Inovasi Teknologi Pertanian. hal: 608-616.

Firmansyah, I., M. Syakir, \& L. Lukman. (2017). Pengaruh Kombinasi Dosis Pupuk N, P, dan K Terhadap Pertumbuhan dan Hasil Tanaman Terung (Solanum melongena L.). Jurnal Hortikultura. Vol. 27 (1): 69-78.

Istikomah, N., \& A.W Kunharjanti. (2017). Perbedaan Jarak Tanam Terhadap Produktivitas Defoliasi Pertama Rumput Mott (Pennisetum purpureum cv. Mott). Jurnal Aves. Vol 11 (2): 14-22.

Jumin, H.B. 1991. Bab III: Tanah dan Lingkungan Tanaman. Dasar - Dasar Agronomi. Cetakan ke-2. CV. Rajawali. Jakarta. hal: 27-47. 
Kurniadinata, O.F., R. Poerwanto, \& A. D. Susila. (2018). The Determination of Phospor Status in Leaf Tisues to Make a Fertilizer Recommendation and Predict Mangosteen Yield. Journal of Tropical of Horticulture. Vol 1 (1): 7-9.

Kusdiana, D., I. Hadist, \& E. Herawati. (2017). Pengaruh Jarak Tanam Terhadap Tinggi Tanaman dan Berat Segar Per Rumpun Rumput Gajah Odot (Pennisetum purpureum cv. Mott). Jurnal IImu Peternakan. Vol 1 (2): 32-37.

Lasamadi, R.D., S.S. Malalantang, Rustandi, \& S.D Anis. (2013). Pertumbuhan dan Perkembangan Rumput Gajah Dwarf (Pennisetum purpureum cv. Mott) yang Diberi Pupuk Organik Hasil Fermentasi EM4. Jurnal Zootek. Vol 32 (5): 158-171.

Ramli, A. K. Paloloang, \& U. A. Rajamuddin. (2016). Perubahan Sifat Fisik Tanah Akibat Pemberian Pupuk Kandang dan Mulsa pada Pertanaman Terung Ungu (Solanum melongena L), Entisol, Tondo Palu. Jurnal Agrotekbis. Vol 4 (2): 160-167.

Roidah, I.S. (2013). Manfaat Penggunaan Pupuk Organik untuk Kesuburan Tanah. Jurnal Universitas Tulungagung Bonorowo. Vol 1 (1): 30-42.

Saputri, L., E.D. Hastuti, \& R. Budihastuti. (2018). Respon Pemberian Pupuk Urea dan Pupuk Kandang Sapi Terhadap Pertumbuhan dan Kandungan Minyak Atsiri Tanaman Jahe Merah [Zingiber officinale (L) Rosc var. rubrum]. Jurnal Biologi. Vol $7(1): 1-7$.

Sari, R.M.P., M. D. Maghfoer, \& Koesriharti. (2016). Pengaruh Frekuensi Penyiraman dan Dosis Pupuk Kandang Ayam Terhadap Pertumbuhan dan Hasil Tanaman Pakchoy (Brassica rapa L. var. chinensis). Jurnal Produksi Tanaman. Vol 4 (5): 342-251.

Silaban, E.T., E. Purba., \& J. Ginting. (2013). Pertumbuhan dan Produksi Jagung Manis (Zea mays sacaratha Sturt. L) pada Berbagai Jarak Tanam dan Waktu Olah Tanah. Jurnal Online Agroekoteknologi. Vol 1 (3): 806-818.

Sirait, J. (2013). Teknologi Budidaya Kambing Berbasis Padang Penggembalaan Pastura Campuran dan Karakterisasi Rumput Gajah Kerdil. dalam Loka Penelitian Kambing Potong. Pusat Penelitian Dan Pengembangan Peternakan Badan Penelitian Dan Pengembangan Pertanian Kementerian Pertanian.

Wahyudin, A., Y. Yuwariah, F. Y. Wicaksono \& R.A.G Bajri. (2017). Respons Jagung (Zea mays I.) Akibat Jarak Tanam Pada Sistem Legowo (2:1) Dan Berbagai Dosis Pupuk Nitrogen Pada Tanah Inceptisol Jatinangor. Jurnal Kultivasi. Vol 16 (3): 507-513. 